\title{
Absceso retroperitoneal gigante abocado a piel
}

\author{
Giant retroperitoneal skinned abscess
}

Jaime Alonso-Gómez ${ }^{1}$, Mercedes Flores-Cortés ${ }^{1}$, María Fátima Ramos-Solís ${ }^{2}$ y Antonio Amaya-Cortijo ${ }^{1}$

Paciente de 86 años con antecedentes de pancolectomía hace 20 años y nefrectomía bilateral parcial hace 3 años.

Acude tras politraumatismo de baja energía 7 días antes, oligosintomática, sólo describe disconfort abdominal y distermia no medida.

La TC muestra una colección de 14 x 14 x 5,7 cm (Figura 1), que desciende por el psoas entre la musculatura paravertebral y riñón derecho, alcanzando piel (Figura 2).

Drenado bajo anestesia local, se obtuvieron $350 \mathrm{cc}$ de pus, dejando un drenaje de Penrose. Ingresada con antibioterapia. Fue dada de alta a los 7 días, tras control de TC sin hallazgos. Dos meses más tarde, la paciente es controlada sin incidencias $\mathrm{y}$ es dada de alta.

\section{Discusión}

El traumatismo suele ser una causa frecuente de absceso retroperitoneal ${ }^{1}$, en nuestro caso se debe a un gran hematoma sobreinfectado. La clínica larvada es habitual ${ }^{2} \mathrm{y}$, aunque el drenaje percutáneo es actualmente el tratamiento de elección ${ }^{3}$, el hecho de que estuviera adyacente a la piel permitió un drenaje directo con una satisfactoria evolución.

\section{Responsabilidades éticas}

Protección de personas y animales. Los autores declaran que para esta investigación no se han realizado experimentos en seres humanos ni en animales.

Confidencialidad de los datos. Los autores declaran que en este artículo no aparecen datos de pacientes.

Conflictos de interés: no hay.

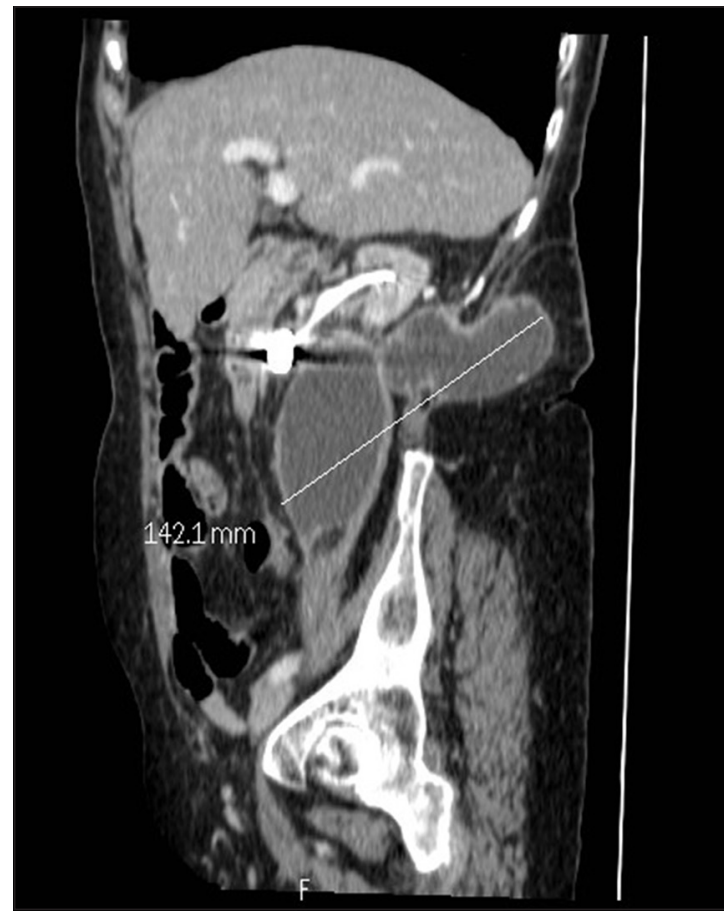

'Servicio de Cirugía General y Digestiva.

2Servicio de Radiología Hospital San Juan de Dios del Aljarafe. Bormujos, Sevilla, España.

Recibido 2020-09-10 y aceptado 2020-09-15

Correspondencia a: Dr. Jaime Alonso-Gómez jaimealonsogomez@hotmail. com
Figura 1. Corte sagital. Absceso $14 \mathrm{~cm}$.

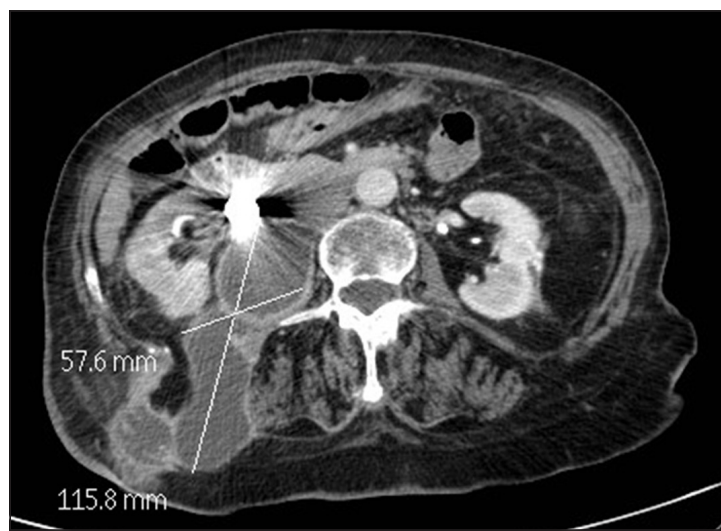

Figura 2. Corte axial. Absceso $5,7 \mathrm{~cm} \times 11,5 \mathrm{~cm}$. 


\section{IMÁGENES Y CIRUGÍA}

\section{Bibliografía}

1. Fang JF, Chen RJ, Lin BC, Hsu YB, Kao JL, Kao YC, et al. Retroperitoneal laparostomy: an effective treatment of extensive intractable retroperitoneal abscess after blunt duodenal trauma. J Trauma 1999;46:652-5. doi: 10.1097/00005373-19990400000015. PMID: 10217229.

2. Mallia AJ, Ashwood N, Arealis G, George A, Ilias G. Retroperitoneal abscess: an extra-abdominal manifestation. BMJ Case Rep. 2015;2015:bcr2014207437. doi: 10.1136/bcr-2014-207437. PMID: 25576509 .
3. Akhan O, Durmaz H, Balcı S, Erdem B, Türkmen Ç, Devrim A. Percutaneous drainage of retroperitoneal abscesses: variables for success, failure, and recurrence. Diagn Interv Radiol. 2020;26:12430. doi: 10.5152/dir.2019.19199. PMID: 32116220. 